\title{
A Rare Location: Actinomyces in Tongue
}

\author{
Çok Nadir Bir Yerleşim : Dilde Aktinomiçes
}

Fatma Bilgen,

Yakup Duman,

Mehmet Bekerecioglu

Kahramanmaras Sutcu Imam University, Faculty of Medicine, Department of Plastic Reconstructive and Aesthetic Surgery, Kahramanmaras

Geliş Tarihi/Received: 21 May 2017 Kabul Tarihi/Accepted: 30 September 2017

\begin{tabular}{l} 
Öz \\
\hline Aktinomikozis, kültürde zor üretilebilen gram pozitif anaerobik bir bakterinin neden olduğu kronik süpüratif \\
bir infeksiyondur. Sıklıkla servikofasial, respiratuar ve gastrointestinal sistemden izole edilmektedir. \\
Servikofasial yerleşimli olanlara sıklıkla maksillafasiyal travma ve diş manipulasyonu eşlik etmektedir. \\
Çalışmada, 45 yaşında bayan hasta travma, dental girişim ve aile öyküsünde anlamlı bulgu olmayan \\
aktinomiçes vakası sunulmaktadır. \\
Anahtar Kelimeler: aktinomiçes, dil, nadir \\
Abstract \\
Actinomyces is a chronic suppurative infection caused by Gram positive anaerobic bacteria which grows \\
hardly in bacterial culture. It is commonly isolated from cervicofacial, respiratory, and gastrointestinal \\
system. Its exact pathogenesis is still unknown. Actinomyces located in the cervicofacial region is \\
frequently accompanied by maxillofacial trauma and dental procedures. Herein, we report a 45 -year-old \\
female case of actinomyces in tongue which was treated with antibiotherapy and good oral hygiene. \\
Keywords: actinomyces, tongue, rare
\end{tabular}

\section{INTRODUCTION}

Actinomyces is a chronic suppurative infection caused by Gram positive anaerobic bacteria which grows hardly in bacterial culture (1). The most common type is Actinomyces İsraelii, but rare species such as $A$. naeslundii, odontolyticus or viscosus can also cause the disease. It is a commensal microorganism which is independently present in the nature and the etiology of the disease is almost endogenous $(1,2)$. It is commonly isolated from cervicofacial (50\%), respiratory $(17 \%)$, and gastrointestinal system $(23 \%)$ (2). Actinomyces located in cervicofacial region is frequently accompanied by maxillofacial trauma and dental procedures. The lesions in this region appear as purplish, purulent running lesions with a central necrotic area $(2,3)$.

The location of actinomyces infection on tongue is very rare and it constitutes less than $3 \%$ of all cases of actinomyces (3).

Herein, we report a female case of a painless mass covered with mucosa on the anterior $2 / 3$ of the tongue without a history of trauma.

\section{CASE REPORT}

A 45-years-old female patient was admitted to our clinic with a complaint of a painless mass on tongue which gradually increased in size within the past three months. There was no history of trauma and dental procedure and there was no significant finding in the family history.

On intraoral examination, a uniformly bounded, swollen, painless mass of $12 \times 14 \mathrm{~mm}$ in size without ulceration and which is covered with normal mucosa of tongue was detected. There was no limitation of movement in tongue (Figure 1). There were no cervical lymphadenopathy and laboratory abnormalities.

A written informed consent was obtained from the patient and she was operated under local anesthesia. The mass was excised and pathologically examined (Figure 2). The result of pathological examination was reported as actinomyces mycetoma. The patient was administered antibiotic treatment with penicillin and she was recommended to take care of a good oral hygiene. At one and three months and one year of follow-up, no recurrence was observed.

\section{DISCUSSION}

Actinomyces is a chronic granulomatous disease caused by Gram positive microaerophilic bacteria in the actinomyces genus $(1,2)$. The most common etiological agent was demonstrated to be A. Israilli (2). It can also result from secondary to trauma 


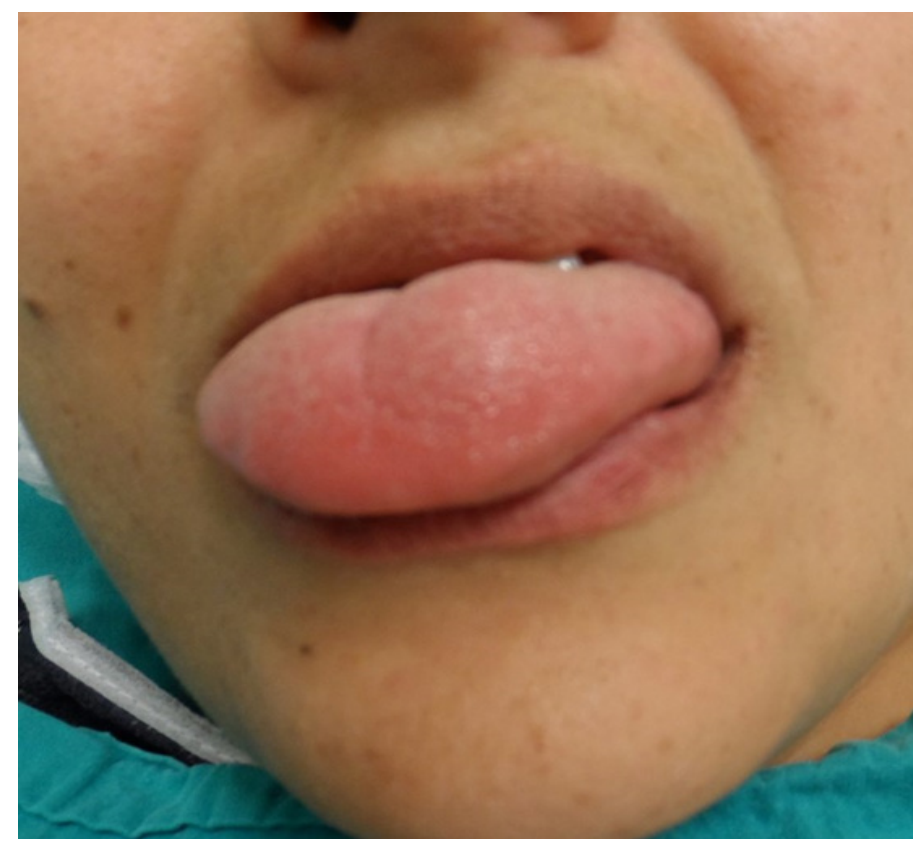

Figure 1. Appearance of the tongue.

in regions with poor hygiene, particularly in oral mucosa, tooth cavity and tonsillar crypts. There are also respiratory, gastrointestinal, and female genital system localizations (1-3).

Pathogenesis of actinomyces has not been exactly explained yet. The organism cannot directly penetrate the healthy tissue; therefore, mucosal damage is necessary for being invasive. By destructing the healthy tissue, it develops granulation tissue in in environment rich in vascular structures and in anaerobic environment $(3,4)$. It can cause development of more than one abscess in small bones and soft tissue lesions and these can form sinus tractus during healing and can reach the surface. In chronic lesions, sulphur granules representing bacterial colonies can be also detected within yellowish purulent discharge $(4,5)$.

Actinomyces typically present with multiple abscess formation and the most common symptoms are swelling and woody stiffness in soft tissue on palpation. This was thought to be caused by formation of dense fibrotic reaction around the necrotic area in the center of the lesion which was demonstrated in histopathological examination. As the clinical symptoms are non-specific, it is often misdiagnosed as a neoplasm. As a result, it is beneficial to perform clinical, radiological, histopathological, and microbiological examinations simultaneously (3-5). In

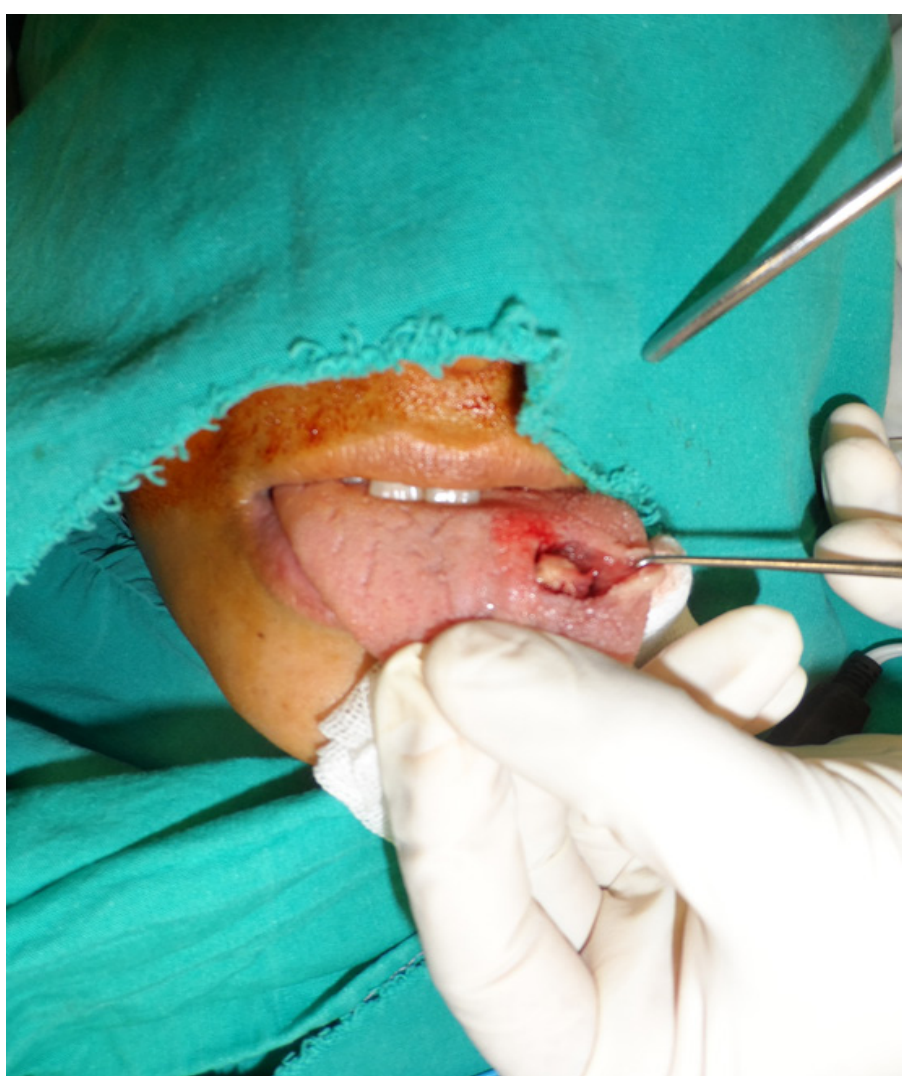

Figure 2. Appearance of mass in tongue.

a study, Dickson-Gonzalez et al. (6) initially diagnosed a lesion located in the upper jaw as a carcinoma; and however, when the biopsy of the lesion was repeated, they reported the pathology as actinomyces infection. Actinomyces in tongue is rare and it constitutes less than $3 \%$ of all actinomyces cases $(3,6)$. In a 20 -year literature review, Brignall and Gillhooly reported that the number of cases with actinomyces in tongue was only seven. In another study in 2006, it was reported that the number of cases with actinomyces in tongue was not more than 15 (7). This was thought to be caused by histophysiological characteristics of the tongue. Tongue forms an environment which is resistant to bacterial adherence and bacterial growth due to its keratinous mucosa, its parenchyma rich in vascular structures, its large range of motion, and mechanical cleaning properties of salivation (8).

Actinomyces in tongue often localizes in the lateral part of median sulcus, deep to the anterior $2 / 3$ of extrinsic and intrinsic muscles of tongue, and it presents as a mass with moderate pain and slight mobility (9). Dysphagia usually accompanies the pain $(4,9,10)$. However, there was no dysphagia and pain 


\section{in our case.}

In addition, actinomyces in tongue can mimic other infections such as nocardiasis or tongue abscess and neoplasms (i.e., neuroma, metastatic tumor). The main diagnostic method is the detection of sulphur granules in the histopathological examination of material obtained from sinus tractus, abscess material or the lesion $(5,11)$.

Excision of fibrotic lesions in particularly complicated cases or drainage together with marsupialization of sinus tractus in diffuse abcess, accompanied with medical therapy is often necessary to tailor a treatment. High-dose penicillin is the firstline antibiotic treatment. Clindamycin, erythromycin, tetracycline, and lincomycin are among the other treatment options (4-12). In the present case, as the lesion formed a mass with hard consistency, excision was performed initially and antibiotic therapy was given according to the results of histopathological examination.

However, actinomyces can recur after months or years and long-term antibiotic therapy prevents the risk of recurrence (10-12).

In the present case, as the pathological diagnosis following excision was actinomyces and as it was sensitive to penicillin, we administered penicillin and penicillin $\mathrm{G}$ for four weeks. During a 12-month followup, recurrence was not observed and the lesion was found to be completely healed.

\section{CONCLUSION}

In conclusion, actinomyces in tongue is a difficult condition to diagnose, particularly when it does not cause prominent findings and it can be misdiagnosed as tumoral lesions. Biopsy from the expanded and hypertrophied lesions in oral region is essential for the diagnosis. The main approach in treatment is complete removal of the lesion together with the surrounding infected tissue and subsequent administration of convenient antibiotic at sufficient doses and durations.

Conflict of interest: Authors declare that there is no conflict of interest between the authors of the article.

Financial conflict of interest: Authors declare that they did not receive any financial support in this study.

Address correspondence to: Fatma Bilgen, Kahramanmaras Sutcu Imam University, Faculty of Medicine, Department of Plastic Reconstructive and Aesthetic Surgery, Kahramanmaras Phone: +905057280165 e-mail: fatmabilgen81@gmail.com

\section{REFERENCES}

1. Belmont MJ, Behar PM, Wax MK. Atypical presentation of actinomycosis. Head Neck 1999;21:264-8.

2. Palonta F, Preti G, Vione N, et al. Actinomycosis of the masseter muscle: Report of a case and review of the literature. J Craniofac Surg 2003;14:915-8.

3. Zamarro L, Pérez M.L, Soriano J.A, et al. Base tongue actinomycosis. Acta Otorrinolaringol Esp 2005;56:222-5.

4. Habibi A, Salehinejad J, Sagha S, et al. Actinomycosis of the tongue. Arch Iranian Med 2008;11(5):566-8.

5. Benhoff DF. Actinomycosis: Diagnostic and therapeutic consideration and a review of 32 cases. Laryngoscope 1984;94:1198-17.

6. Lavilla MJ, Benítez F, García M, et al. Actinomicosis lingual: Dificultad de diagnóstico. Revisión de la bibliografía. Acta Otorrinolaringol Esp 2000;51(1):80-4.

7. Brignall ID, Gilhooly M. Actinomycosis of the tongue. A diagnostic dilemma. Br J Oral Maxillofac Surg 1989;27:24953.

8. Atespare A, Keskin G, Ercin C, et al. Actinomycosis of the tongue: A diagnostic dilemma. J Laryngol Otol 2006;120:6813.

9. Gerbino G, Bernardi M, Secco F, et al. Actinomycosis of the tongue: Report of two cases and review of the literature. Minerva Stomatol 1998;45:98-101.

10. Ficarra G, Di Lollo S, Pierleoni F, et al. Actinomycosis of the tongue: A diagnostic challenge. Head Neck 1993;15:53-5.

11. Happonen RP, Viander M. Comparison of fluorescent antibody technique and conventional staining methods in diagnosis of cervicofacial actinomycosis. J Oral Pathol 1982;11:417-25.

12. Martin MV. Antibiotic treatment of cervicofacial actinomycosis for patients allergic to penicillin: A clinical and in vitro study. Br J Oral Maxillofac Surg 1985;23:428-34. 